\title{
DESKRIPSI POLA SALURAN TATANIAGA PALA (Myristica fraggan haitt) DI KENAGARIAN TANJUNG SANI KECAMATAN TANJUNG RAYA KABUPATEN AGAM
}

\section{Description of Nutmeg's (Myristica Fraggan Haitt) Marketing Chanels Pattern of Tanjung Sani Tanjung Raya Subdistrict Agam District}

\section{Devi Analia'), Syofyan Fairuzi'2) Faidil Tanjung3), dan Ramita Sari Pimura4) 1,2,3 Dosen Fakultas Pertanian Universitas Andalas Padang Sumatera Barat e-mail: analia_devi@yahoo.com, faidilt@yahoo.com,ramithasari@ymail.com}

\begin{abstract}
The research purpose is to describe nutmeg's marketing channel pattern and to identity of marketing instutional function that involves in marketing channel. This research was conducted in Juli - Augustus 2015. Location was chosen purposively with a reason that this district has the largest production in West Sumatra. The research method used is survey and descriptive analysis. The survey is doing by following marketing channel pattern that happen and observation activity that doing by farmer as producers to middlemen or finar consumers. The result shows that there are 2 patter of marketing channel in location. First pattern marketing channel : farmers - man in village. Second patter marketing channel : farmers - whole saler. Their activity according to marketing function consist of exhange function(selling and buying), phisic function (transportation, saving, sortation) and fasility (finance, market information, risk management). As important comodity that have contribute to gaverment, this comodity need goverment support to increase selling value and production. By the support it will imcrease farmers revenue.
\end{abstract}

Keyword : nutmeg, markleting channel, whole seller, man invillage and marketing function

\section{PENDAHULUAN.}

Prioritas pembangunan yang diletakkan pada pembangunan bidang ekonomi dititik beratkan pada sektor pertanian. Dalam pembangunan pertanian diarahkan dapat meningkatkan produksi yang berguna untuk memenuhi kebutuhan pangan dan kebutuhan industri dalam negeri, meningkatkan ekspor, meningkatkan pendapatan petani, memperluas kesempatan kerja dan mendorong pemerataan kesempatan berusaha. Sektor perkebunan mempunyai peranan yang penting terutama dalam meningkatkan kemakmuran dan kesajahteraan rakyat, perolehan nilai tambah dan daya saing, serta optimalisasi 
pengelolaan sumber daya alam secara berkelanjutan (Direktorat Jenderal Perkebunan, 2006).

Pala merupakan tanaman asli Indonesia yang merupakan tanaman buah berhabitus pohon tinggi. Tanaman ini berasal dari Banda dan Maluku menyebar ke Pulau Jawa, pada saat perjalanan Marcopollo ke Tiongkok yang melewati pulau Jawa pada tahun 1271 sampai 1295 pembudidayaan tanaman pala terus meluas sampai Sumatera. Komoditas berpotensial yang mampu mensuplai 60$75 \%$ kebutuhan pangsa pasar dunia serta mempunyai banyak manfaat baik dalam bentuk mentah atau produk turunannya. Pasar utama tujuan ekspor pala Indonesia (dari sisi volume) adalah Vietnam, Amerika Serikat, Belanda, Jerman dan Italia. Produksi pala Indonesia pada tahun 2011 mencapai 15.793 ton, yang dihasilkan dari luas areal produksi 118.345 hektar sebagian besar oleh perkebunan rakyat yaitu sekitar 99 persen, dengan cara penanganan pasca panen yang masih tradisional dengan peralatan seadanya.

Pelaku utama dalam rantai nilai komoditas pala adalah para petani dan pedagang. Jumlah petani yang cukup besar menjadi penentu dalam kontinuitas pasokan serta kualitas pala. Namun, lemahnya kapasitas petani selama ini menjadikan posisinya yang sangat lemah dalam rantai perdagangan pala, dan mengakibatkan rendahnya pendapatan yang diterima oleh petani.

Masalah yang dihadapi di Indonesia adalah kurangnya keinginan berproduksi pada tingkat petani, tidak ada keinginan untuk mengadakan penanaman baru dan usaha-usaha lain untuk menaikkan produksi karena persentase harga yang diterima oleh petani relatif rendah dibandingkan dengan bagian yang diterima golongan-golongan lain. Persentase harga yang rendah dan pendapatan yang diterima oleh petani mengurangi semangat petani untuk berproduksi (Mubyarto, 1989). Kondisi demikian disebabkan belum adanya kepastian tataniaga pala yang mengakibatkan harga dan pasokan tidak sesuai dengan yang diharapkan sehingga petani hanya bisa bergantung kepada pedagang yang ada di daerah. Kemampuan petani dalam budidaya dan pengolahan pala yang kurang (pengetahuan dan alat pendukung), mengakibatkan rendahnya kualitas yang dihasilkan serta minimnya akses informasi pasar dan lembaga pendukung mengakibatkan lemahnya kekuatan pelaku tataniaga dalam rantai nilai pala.

Salah satu sentra pala di Sumatera Barat adalah Kabupaten Agam. Sebagian besar wilayah Kabupaten Agam merupakan lahan perkebunan yang terdiri dari 25.868,10 hektar kebun campuran, 15.256,62 hektar perkebuntan rakyat dan 21.462,86 hektar perkebunan besar, yang digunakan untuk menanam aneka tanaman perkebunan seperti kelapa, kelapa sawit, karet, cengkeh, kulit manis, kopi, gardamunggu, kemiri, pinang, kakao, pala, tebu, tembakau dan gambir (Bappeda Kabupaten Agam dan Badan Pertanahan Nasional, 2010). Sentra produksi pala di Kabupaten Agam adalah Kecamatan Tanjung Raya tepatnya yaitu di Kanagarian Tanjung Sani yang jumlah produksi tanaman 
paling tinggi. Tahun 2013 produksi pala di Kecamatan tersebut sebesar 542 ton dengan luas areal 529 hektar (BPS, 2013).

Pertanian pala di Kecamatan Tanjung Raya umumnya bersifat subsisten, dimana hasil penjualan pala tersebut digunakan untuk memenuhi kebutuhan rumah tangga. Kebutuhan rumah tangga petani yang beragam dan tidak memiliki jalur distribusi sendiri dalam penjualan hasil produksinya. Biasanya petani lebih banyak menjual pala sesuai dengan kebutuhan keuangan keluarga. Posisi petani hanya sebagai penerima harga yang ditetapkan oleh pedagang pengumpul. Jadi berapapun harga yang ditetapkan oleh pedagang pengumpul, petani akan tetap menjual hasil produksinya. Lebih lanjut, proses tataniaga pala dari petani memerlukan waktu yang cukup lama. Banyaknya lembaga niaga yang terlibat dalam tataniaga mempengaruhi panjang pendeknya rantai tataniaga. Panjang pendeknya rantai tataniaga ditandai dengan jumlah pedagang perantara yang dilalui dari petani sampai ke konsumen akhir.

Dalam permasalahan tersebut, maka perlu dilakukan penelitian guna untuk mendeskripsikan pola saluran tataniaga pala dan fungsi tataniaga yang dilakukan masing - masing lembaga niaga yang terlibat sehingga terlihat gambaran tataniaga yang dilakukan petani dan lembaga niaga pala.

\section{METODE PENELITIAN}

Penelitian ini dilaksanakan di Kanagarian Tanjung Sani, Kecamatan Tanjung Raya Kabupaten Agam, Sumatera Barat dengan pemilihan lokasi dilakukan secara sengaja (purposive), berdasarkan pertimbangan daerah penghasil komoditi pala terbanyak di Sumatera Barat. Penelitian dimulai pada bulan Juli 2015 sampai dengan bulan Agustus 2015.

Metode yang digunakan dalam penelitian ini adalah metode survei. Penelitian dilakukan secara berantai dengan mengamati pola saluran tataniaga pala dari petani sampel sebagai produsen di Nagari Tanjung Sani Kecamatan Tanjung Raya sampai ke tingkat pedagang. Pengambilan petani sampel dipilih dari kelompok tani pala di daerah penelitian dengan penarikan sampel secara stratified random sampling. Pedagang sampel diambil secara berantai dari petani ke pedagang yang menjual/beli pala dari daerah penelitian.

Data primer, diperoleh melalui wawancara dengan menggunakan kuisioner pada petani dan lembaga tataniaga yang berperan aktif dalam mekanisme tataniaga pala dan pengamatan langsung di lapangan. Data sekunder diperoleh dari studi kepustakaan dan instansi lembaga yang terkait dengan masalah penelitian. Aspek dan variabel data yang dikumpulkan yaitu mendeskripsikan saluran tataniaga pala dan fungsi tataniaga yang dilakukan oleh masing-masing lembaga tataniaga yang terlibat dalam pemasaran pala. 


\section{HASIL DAN PEMBAHASAN}

Secara geografis kecamatan Tanjung Raya terletak pada $100^{00} 05$ - $100^{016}$ Bujur Timur dan 0012 - 0025 Lintang selatan. Kecamatan Tanjung Raya terletak pada ketinggian 100 - 1000 mdpl. Ketinggian optimal untuk tanaman pala adalah 500 - 700 mdpl. Kecamatan Tanjung Raya mempunyai luas $\pm 244,03 \mathrm{Km} 2$ yang terdiri dari sembilan nagari dengan nagari yang terluas adalah Nagari Tanjung Sani sebesar \pm 75,03 Km2 (Tanjung Raya Dalam Angka, 2013).

Luas Kabupaten Agam adalah 223.230 hektar. Sebagian besar wilayah Kabupaten Agam merupakan lahan perkebunan yang terdiri dari 25.868,10 hektar kebun campuran, 15.256,62 hektar perkebuntan rakyat dan 21.462,86 hektar perkebunan besar, yang digunakan untuk menanam aneka tanaman perkebunan seperti kelapa, kelapa sawit, karet, cengkeh, kulit manis, kopi, gardamunggu, kemiri, pinang, kakao, pala, tebu, tembakau dan gambir (Bappeda Kabupaten Agam dan Badan Pertanahan Nasional, 2010). Dari sejumlah komoditas perkebunan yang diusahakan oleh petani, pala merupakan salah satu komoditi perkebunan yang cukup banyak diusahakan.

\section{Saluran Tataniaga Pala}

Saluran tataniaga pala di daerah penelitian dilakukan dengan menelusuri kegiatan tataniaga dari petani hingga ke pedagang akhir. Hasil pengamatan dilapangan diketahui 2 saluran tataniaga pala yang terjadi yaitu : (a) Pola I : Petani $\rightarrow$ PPD $\rightarrow$ Eksportir, dan (b) Pola II : Petani $\rightarrow$ PAD $\rightarrow$ Eksportir

Berdasarkan penelitian yang dilakukan dilapangan diketahui jumlah petani yang melakukan penjualan pala yang dihasilkan ke PPD adalah sebesar $43,33 \%$ pada pola saluran I. Beberapa petani juga melakukan penjualan sebanyak $56,67 \%$ ke PAD. Hal ini dikarenakan harga yang ditawarkan PAD lebih tinggi dari PPD dan penjualan yang dilakukan dekat dari daerah penelitian. Petani dapat menjual pala rata - rata sebanyak $5 \mathrm{~kg}-15 \mathrm{~kg}$ dalam satu kali penjualan dengan harga jual pada saat penelitian adalah Rp 35.000/kg. Petani dapat memilih dan mempertimbangkan penjualan pala yang dimiliki sesuai harga yang ditawarkan pedagang tergantung situasi dan kondisi petani pada saat itu.

Pada daerah penelitian diketahui jumlah tanaman pala semakin berkurang tanaman mati mendadak karena terserangnya gangguan penyakit akar dan batang sehingga produksi yang dihasilkan semakin sedikit. Selain itu harga jual pala yang mengalami fluktuasi dan dapat berubah secara tak menentu menjadikan sebagian dari petani beralih profesi ke keramba jaring apung (KJA) yang lebih menguntungkan saat ini.

Adapun Saluran dan volume penjualan pala di Kanagarian Tanjung Raya dapat dilihat pada Gambar 1. Gambar ini menjelaskan bahwa total produksi pala petani yang dipasarkan ke konsumen akhir yaitu eksportir di Kota Padang melalui PPD sebesar 32,39\% (Pola I), dan melalui petani ke PAD sebesar 67,61 \% (Pola II).

230 | Devi Analia, Syofyan F, Faidil T, dan Ramita S Pimura, Deskripsi pola... 


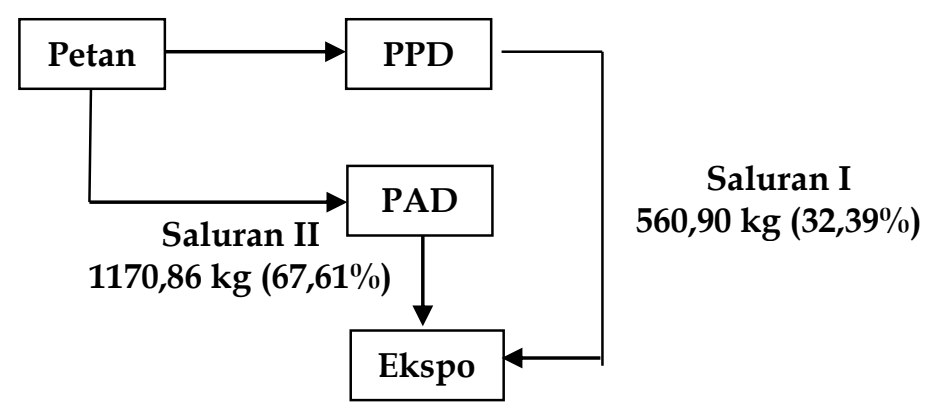

Gambar 1. Pola Saluran Tataniaga Pala

\section{Lembaga - Lembaga Niaga dan Fungsi - Fungsi Tataniaga yang dilakukan}

Lembaga tataniaga mempunyai fungsi masing - masing yan dilakukan terhadap tataniaga pala. Fungsi - fungsi tersebut terdiri dari fungsi pertukaran, fungsi fisik dan fungsi fasilitas yang berfungsi memperlancar penyaluran barang sampai ke konsumen akhir.

\section{Fungsi - fungsi tataniaga pola saluran I}

\section{a. Petani}

Fungsi tataniaga yang dilakukan petani rata - rata dalam sebulan dengan jumlah panen yang berbeda - beda. Petani dapat menjual pala dalam jumlah 5 $15 \mathrm{~kg}$ pada satu kali penjualan. Petani dapat menjual pala 2 - 3 kali penjualan dalam sebulan tergantung pala yang dihasilkan pada saat panen. Hal ini juga dipengaruhi kondisi tanaman yang tumbuh karena pada saat peninjauan dilokasi penelitian ada beberapa tanaman yang tidak berproduksi atau mati karena serangan penyakit pada batang tanaman.

\section{i. $\quad$ Fungsi Pertukaran}

Fungsi pertukaran yang dilakukan petani adalah fungsi penjualan pala ke pedagang yang berada di sekitar lokasi penelitian. Petani yang menjual pala ke PPD adalah sebanyak $43,33 \%$. Pada fungsi penjualan yang dilakukan petani adalah dijemput oleh pedagang ke rumah - rumah dan diantar ke lokasi pedagang sekitar daerah penelitian. Dengan penjemputan, petani akan mudah melakukan penjualan dengan tidak memakan waktu, biaya serta adanya faktor langganan antara petani dan pedagang yang sudah lama karena terbiasa. Pedagang biasanya akan datang pada setiap hari senin dan rabu ke rumah - rumah petani. Transaksi jual/beli yang dilakukan antara petani dan pedagang dengan sederhana. Tawar - menawar harga dilakukan berdasarkan tingkat kekeringan pala yang dijual/belikan. Tingkat kekeringan pala dilihat berdasarkan warna yang putih kebeningan, ringan dan keras pada pala. Diluar dari kesepakatan itu, pedagang memiliki hak 
untuk mengurangi harga pembelian pala karena tingkat kekeringan yang kurang sehingga pedagang harus melakukan pengolahan lagi pala yang belum kering sesuai dengan permintaan pasar. Harga jual pala saat itu adalah pala kering sebesar Rp 35.000/kg, pala basah (kadar air $20-30 \%$ ) seharga Rp 20.000/kg.

\section{ii. $\quad$ Fungsi Fisik}

Fungsi fisik yang dilakukan petani berupa fungsi pengangkutan, fungsi pengolahan dan fungsi penyimpanan. Fungsi pengangkutan dilakukan petani untuk mengangkut pala yang sudah dipanen dan dibawa ke pedagang pengumpul dengan menggunakan angkutan sewa.

Fungsi pengolahan yang dilakukan petani adalah pembelahan serta pengeringan pala yang sudah dipanen. Pala yang sudah dipanen, dikumpulkan dalam satu wadah yang selanjutnya dilakukan pembelahan daging buah menjadi 2 bagian. Setelah ditemukan biji pala yang diselimuti fuli, kemudian dipisahkan. Pala yang masih bercangkang kemudian diasap. Selain diasap, biji pala juga bisa dijemur untuk dapat memecahkan cangkang dengan mudah. Proses penjemuran pala dilakukan tidak berpaparan langsung dengan cahaya matahari, hanya diangin - anginkan selama lebih kurang 2 - 3 hari, sedangkan pengasapan dilakukan hanya sebentar saja lebih kurang $1-2$ jam. Hal ini juga berpengaruh terhadap kandungan minyak jika terlalu lama pengasapan. Fungsi penyimpanan dilakukan petani untuk mengumpulkan pala sampai sudah cukup banyak dijual.

\section{iii. Fungsi Fasilitas}

Fungsi fasilitas yang dilakukan petani disini adalah fungsi pembiayaan. Fungsi pembiayaan tersebut adalah biaya yang dikeluarkan petani dalam aktivitas panen sampai pala terjual ke pedagang pengumpul. Aktivitas pembiayaan tersebut diantaranya biaya angkut pala yang dikeluarkan petani untuk menjual pala ke pedagang pengumpul dan Biaya penyusutan alat yaitu pisau/parang yang digunakan untuk pembelahan buah pala yang dipanen.

\section{b. Pedagang Pengumpul Desa (PPD)}

Pedagang pengumpul desa adalah pedagang yang berada di sentra produksi pala dan membeli pala langsung dari petani. Pedagang pengumpul yang terlibat dalam tataniaga pala adalah sebanyak satu orang.

\section{i. $\quad$ Fungsi Pertukaran}

Fungsi pertukaran yang dilakukan pedagang pengumpul desa adalah fungsi pembelian dan fungsi penjualan. Pembelian dilakukan ditempat 
usaha dengan penerimaan penjualan pala yang diantar oleh petani itu sendiri dan dijemput oleh pedagang.

\section{ii. $\quad$ Fungsi Fisik}

Pada fungsi fisik pedagang pengumpul desa melakukan fungsi pengangkutan, fungsi penyimpanan, penyortiran, pengepakan dan pengolahan. Fungsi Pengangkutan dilakukan untuk pembelian pala dari petani. Penyimpanan pala dilakukan pedagang pengumpul desa di dalam gudang yang sudah disediakan. Penyimpanan menggunakan karung agar pala yang disimpan cukup banyak untuk dapat dijual kembali ke eksportir. Pala yang sudah dibeli dari petani kemudian disortir untuk memisahkan pala yang sudah kering dan yang belum kering. Ini dilakukan pedagang agar penjualan pala nanti dapat sesuai dengan permintaan eksportir sehingga harga yang ditawarkan lebih tinggi. Pala yang belum kering kemudian dilakukan pengolahan dengan menjemur hingga pala tersebut kering dengan bentuk dan warna yang disesuaikan. Fungsi pengepakkan dilakukan untuk penyimpanan dan wadah pala dalam melakukan penjualan pala sehingga tidak membutuhkan tempat yang luas untuk penyimpanan tersebut.

\section{iii. $\quad$ Fungsi Fasilitas}

Fungsi fasilitas yang dilakukan pedagang terhadap pala adalah informasi pasar dan pembiayaan. Informasi pasar yang dilakukan adalah informasi yang terkait dengan harga penjualan pala dan kebutuhan pasar dari sumber - sumber pedagang maupun dilingkungan pasar. Informasi yang diperoleh pada saat melakukan penjualan pala pada eksportir maupun berita dari mulut ke mulut. Jika harga yang diterima pedagang pengumpul saat itu Rp 55.000/kg maka prediksi terhadap harga pala untuk satu bulan kedepan berkisaran Rp 55.000/kg.

Fungsi penanggungan resiko terkait dengan harga yang diterima berdasarkan kadar air pala pada saat dijual. Fungsi pembiayaan terkait dengan biaya - biaya yang dikeluarkan selama proses penjualan dilakukan. Biaya - biaya tersebut diantaranya biaya penyusutan alat yaitu timbangan, gudang dan kendaraan.

\section{c. Pedagang Antar Daerah (PAD)}

Pedagang antar daerah adalah pedagang yang berada di sentra produksi pala dan membeli pala langsung dari petani maupun dari pedagang pengumpul. Fungsi - fungsi tataniaga yang dilakukan oleh pedagang adalah fungsi pertukaran, fungsi fisik dan fungsi fasilitas. Fungsi pertukaran yang dilakukan pedagang antar daerah adalah fungsi pembelian dan fungsi penjualan. Fungsi pembelian yang dimaksud adalah pembelian pala dari petani dan pedagang 
pengumpul di daerah penelitian. Pembelian dilakukan ditempat usaha dengan penerimaan penjualan pala yang diantar oleh petani itu sendiri dan dijemput oleh pedagang.

\section{i. Fungsi Fisik}

Fungsi fisik pedagang antar daerah terdiri dari fungsi pengangkutan, penyimpanan, penyortiran, pengepakan dan pengolahan. Pengangkutan dilakukan untuk pembelian pala dari petani. Penyimpanan pala dilakukan pedagang antar daerah di dalam gudang yang sudah disediakan. Penyimpanan menggunakan karung agar pala yang disimpan cukup banyak untuk dapat dijual kembali ke eksportir.

Pala yang sudah dibeli kemudian disortir untuk memisahkan pala yang sudah kering dan yang belum. Pala yang belum kering dilakukan penjemuran. Untuk proses penjemuran dan penyortiran, pedagang tidak mengeluarkan biaya karena proses ini serta pengepakkan dilakukan sendiri oleh pedagang dengan suami dengan tujuan untuk mengurangi biaya dan sebagai pengisi waktu luang. Fungsi pengepakkan dilakukan untuk penyimpanan dan wadah karung.

\section{ii. $\quad$ Fungsi Fasilitas}

Fungsi fasilitas yang dilakukan pedagang terhadap pala adalah informasi pasar dan pembiayaan. Informasi pasar yang dilakukan adalah informasi yang terkait dengan harga penjualan pala dan kebutuhan pasar dari sumber - sumber pedagang antar daerah maupun dilingkungan pasar. Fungsi pembiayaan terkait dengan biaya - biaya yang dikeluarkan selama proses penjualan dilakukan. Biaya - biaya tersebut diantaranya biaya penyusutan alat yaitu timbangan, gudang dan kendaraan.

\section{Permasalahan dalam Tataniaga Pala}

\section{Permasalahan Petani}

Harga pala yang ditekan oleh satu orang atau satu pedagang besar (eksportir) menyebabkan terhalangnya pengembangan usahatani pala itu sendiri. Tidak hanya itu, masalah penyakit yang menyerang tanaman pala menjadikan petani untuk beralih usaha ke Keramba Jaring Apung (KJA) karena tidak adanya kejelasan dan bantuan terhadap penanganan lebih lanjut terhadap tanaman pala yang mereka miliki. Serangan penyakit pada tanaman berpengaruh pada produksi pala yang dihasilkan petani serta terhadap standar dan mutu serta cara pengolahan pala yang sesuai dengan permintaan pasar. Seperti yang dijelaskan pada standar kandungan aflatoksin ditetapkan Uni Eropa sebesar $5 \mu \mathrm{g} / \mathrm{kg}$ dan aflatoksin total 10 mikrogram $/ \mathrm{kg}$ dimana aflatoksin merupakan racun yang berasal dari jamur yang tumbuh pada pala. Penyebabnya 
yaitu kurangnya higenitas, proses pengeringan serta kiurang baiknya penyimpanan, baik oleh pelaku usaha (pedagang) maupun dari petani. Aflatoksin yang merupakan penyebab kanker berpengaruh terhadap mutu pala yang dihasilkan. Penjualan dalam bentuk buah dengan harga yang ditawarkan tidak stabil dibandingkan penjualan dalam bentuk olahan minyak dengan harga yang sangat menjanjikan. Hal ini karena tidak adanya alat olahan minyak yang dimiliki petani disekitar kawasan penelitian.

\section{Permasalahan Pedagang Pengumpul Desa}

Pedagang pegumpul desa pada umumnya memiliki kendala dalam menyesuaikan standar dan mutu pala yang juga berpengaruh pada harga jual. Jika pada pengolahan yang tidak sesuai dengan standar, maka harga yang diterima menurun, dan sebaliknya. Peningkatan kualitas menjadi salah satu cara pedagang pengumpul untuk dapat menaikkan harga jual pala. Meskipun hal itu membutuhkan waktu lama dan adanya penambahan biaya - biaya yang dikeluarkan untuk peningkatan kualitas pala. Salah satunya pengolahan pala menjadi olahan minyak.

Pasokan pala kurang merupakan permasalahan lain yang juga dihadapi. Penyebabnya, penyakit yang menyerang tanaman akan mengurangi jumlah produksi pala yang dihasilkan petani. Selain itu adanya konversi usaha yang dilakukan petani terkait dengan pengaruh harga yang ditawarkan. Apabila harga menarik petani berusaha untuk menambah jumlah tanaman sehingga juga menghasilkan produksi buah yang lebih banyak, sebaliknya kalau harga menjadi tidak menarik (turun) maka mereka mengalihkan usahanya pada usaha KJA (keramba jaring apung). Saat penelitian tanaman pala yang dimiliki petani mulai terkena penyakit batang dan akar yang menyebabkan kematian mendadak sehingga petani beralih ke usaha KJA di danau Maninjau.

\section{Permasalahan pedagang antar daerah}

Pedagang antar daerah yang terlibat dalam tataniaga biji pinang tidak mengalami permasalahan yang serius. Modal yang dimiliki cukup besar dan hubungan baik dengan pedagang pengumpul dan petani selaku pemasok pala. Masalah yang dihadapi pedagang antar daerah adalah pasokan pala yang berkurang dari petani dan pedagang pengumpul menjadikan kurangnya persediaan pala yang dimiliki untuk dijual ke eksportir.

\section{SIMPULAN DAN SARAN}

\section{Simpulan}

Berdasarkan hasil penelitian yang telah dilakukan tentang analisis tataniaga biji pinang di Kanagarian Manggopoh Kecamatan Lubuk Basung 
Kabupaten Agam, dapat disimpulkan bahwa, terdapat dua pola saluran tataniaga pala di Kenagarian Tanjung Sani Kecamatan Tanjung Raya Kabupaten Agam yaitu Pola I : Petani -- Pedagang Pengumpul Desa (PPD), dan Pola II : Petani -- Pedagang Antar Daerah (PAD). Fungsi tataniaga yang dilakukan pelaku dan tataniaga adalah fungsi pertukaran (penjualan dan pembelian), fungsi fisik (pengangkutan, penyimpanan, penyortiran dan pengolahan), fungsi fasilitas (pembiayaan, penanggungan resiko dan informasi pasar).

\section{Saran}

Sebagai komoditi ekspor unggulan yang dapat memberi penambahan devisa negara, diharapkan campur tangan pemerintah dalam peningkatan nilai jual dan produksi pala petani. Selain itu dengan adanya perhatian dari pemerintah dan pihak - pihak lainnya dalam pengembangan dan pemasaran pala, akan terjadinya pengangkatan perekonomian petani pala yang dikhawatirkan akan semakin menurun.

\section{Ucapan Terima Kasih}

Terima kasih penulis ucapkan kepada Lembaga Penelitian dan Pengabdian (LPPM) Universitas Andalas yang telah memfasilitasi penulis dalam melakukan penelitian ini. Terima kasih juga kepada pembimbing yaitu Bapak Dr. Ir. Faidil Tanjung, M.Si yang telah memberikan masukan berkaitan dengan penelitian ini. Terima kasih juga diucapkan kepada Ramita Sari Pimura yang telah membantu dalam penyelesaian penelitian ini. Penulis juga mengucapkan terima kasih kepada Dinas Perkebunan dan Kehutanan Kabupaten Agam, Ketua kelompok tani beserta anggotanya dan kepada pedagang pala yang merupakan sampel dari penelitian ini.

\section{DAFTAR PUSTAKA}

Badan Pusat Statistik Kabupaten Agam. 2013. Tanjung Raya dalam Angka 2013. Kabupaten Agam.

Direktoral Jenderal Perkebunan Provinsi Sumatera Barat. 2006. Laporan Tahunan

Mubyarto.1989. Pengantar Ekonomi Pertanian. LP3ES. Jakarta.

Bappeda Kabupaten Agam dan Badan Pertanahan Nasional. 2010. Perencanaan Lahan Perkebunan 2010. Kabupaten Agam. 